\title{
Physical activity and risk of ovarian cancer: results from the Netherlands cohort study (the Netherlands)
}

Citation for published version (APA):

Biesma, R. G., Schouten, L. J., Dirx, M. J. M., Goldbohm, R. A., \& van den Brandt, P. A. (2006). Physical activity and risk of ovarian cancer: results from the Netherlands cohort study (the Netherlands). Cancer Causes \& Control, 17(1), 109-115. https://doi.org/10.1007/s10552-005-0422-3

Document status and date:

Published: 01/01/2006

DOI:

10.1007/s10552-005-0422-3

Document Version:

Publisher's PDF, also known as Version of record

\section{Please check the document version of this publication:}

- A submitted manuscript is the version of the article upon submission and before peer-review. There can be important differences between the submitted version and the official published version of record.

People interested in the research are advised to contact the author for the final version of the publication, or visit the DOI to the publisher's website.

- The final author version and the galley proof are versions of the publication after peer review.

- The final published version features the final layout of the paper including the volume, issue and page numbers.

Link to publication

\footnotetext{
General rights rights.

- You may freely distribute the URL identifying the publication in the public portal. please follow below link for the End User Agreement:

www.umlib.nl/taverne-license

Take down policy

If you believe that this document breaches copyright please contact us at:

repository@maastrichtuniversity.nl

providing details and we will investigate your claim.
}

Copyright and moral rights for the publications made accessible in the public portal are retained by the authors and/or other copyright owners and it is a condition of accessing publications that users recognise and abide by the legal requirements associated with these

- Users may download and print one copy of any publication from the public portal for the purpose of private study or research.

- You may not further distribute the material or use it for any profit-making activity or commercial gain

If the publication is distributed under the terms of Article $25 \mathrm{fa}$ of the Dutch Copyright Act, indicated by the "Taverne" license above, 


\title{
Physical activity and risk of ovarian cancer: results from the Netherlands Cohort Study (The Netherlands)
}

\author{
Regien G. Biesma $\cdot$ Leo J. Schouten • \\ Miranda J.M. Dirx $\cdot$ R. Alexandra Goldbohm • \\ Piet A. van den Brandt
}

Received: 12 May 2005/ Accepted: 16 August 2005

(C) Springer-Verlag 2006

\begin{abstract}
Objective To investigate the association between nonoccupational physical activity and the risk of ovarian cancer among post-menopausal women.

Methods The Netherlands Cohort Study on Diet and Cancer consists of 62,573 women aged 55-69 years at baseline. Information regarding baseline nonoccupational physical activity and history of sports activity was collected with a self-administered questionnaire in 1986. After 11.3 years of follow-up, 252 cases of invasive epithelial ovarian cancer were available for case-cohort analysis.

Results In multivariate analysis and compared to women who spent less than 30 min per day on physical activity, the rate ratios (RRs) of ovarian cancer for women who spent up to 60,90 and $>90$ min per day were $0.78,0.86$ and 0.72 , respectively $(95 \%$ confidence interval $(\mathrm{CI})$ for the top category, 0.48-1.06; $p$-trend, 0.15). Women who spent more than $2 \mathrm{~h}$ per week on recreational biking and walking
\end{abstract}

R. G. Biesma · L. J. Schouten $(\bowtie)$

Department of Epidemiology, NUTRIM, Maastricht University,

PO Box 616, 6200 MD Maastricht, The Netherlands

e-mail: 1j.schouten@epid.unimaas.nl

Tel.: +31-43-3882390

Fax: $+31-43-3884128$

P. A. van den Brandt · R. G. Biesma - L. J. Schouten Department of Health Organization, Policy, and Economics, CAPHRI, Maastricht University, PO Box 616, 6200 MD

Maastricht, The Netherlands

M. J. M. Dirx

Maastricht Cancer Registry, Comprehensive Cancer Centre Limburg, PO Box 2208, 6201 HA, Maastricht, The Netherlands

R. A. Goldbohm

TNO Nutrition and Food Research, PO Box 360, 3700 AJ Zeist,

The Netherlands had a reduced risk of ovarian cancer $(\mathrm{RR}=0.65 ; 95 \% \mathrm{CI}$ : 0.41-1.01) compared to women who never participated in recreational biking or walking.

Conclusions These data suggest a modest inverse association between moderate physical activity and ovarian cancer risk. Vigorous physical activity was not associated with ovarian cancer risk.

Keywords Ovarian neoplasms · Cohort studies · The Netherlands · Exercise $\cdot$ Physical activity

\section{Introduction}

Ovarian cancer ranks as the fifth most common malignancy among women in Europe with approximately 34,500 newly diagnosed ovarian cancer cases in 1998 [1]. The highest rates are found in Scandinavia, Eastern Europe and North America, while the lowest rates are reported in Africa and Japan [2].

So far, relatively little is known about the etiology of epithelial ovarian cancer. The most consistent risk factor for ovarian cancer is family history of ovarian cancer, while parity and the use of oral contraceptives are associated with a reduced risk of ovarian cancer [2, 3].

Ovarian cancer is a hormone-related cancer and shares several risk factors with breast and endometrial cancer, although not always in the same direction. Several studies have found that increased physical activity is associated with a decreased risk of breast cancer and endometrial cancer [4-6]. However, previous studies relating physical activity and ovarian cancer risk yielded inconsistent findings. Six case-control studies reported a negative association between physical activity and the risk for ovarian cancer [7-12], while one study among female teachers did not find an association [13]. Case-control studies, however, 
are more vulnerable to bias, especially recall bias. Two prospective cohort studies found a significant increased risk for ovarian cancer risk when specifically vigorous physical activity was present $[14,15]$. Another prospective cohort study suggested an inverse association between total physical activity and ovarian cancer risk, however this was not statistically significant [16].

Several mechanisms have been formulated on the role of physical activity in reducing risk for epithelial ovarian cancer. Physical activity may decrease the number of ovulations and damage to epithelial tissue, and thus, would protect against the risk for ovarian cancer [17]. Moderate levels of physical activity may lengthen ovulatory cycles and therefore decrease lifetime exposure to endogenous estrogens and the number of ovulations [18]. It has been argued that the ovarian surface epithelium is an androgenresponsive tissue and that androgens can cause an increase in proliferation and a decrease in cell death [19]. Physical activity leads to reduced body fat which is associated with a lower production of extraglandular estrogen and androgen production [20-22]. Also, it has been proposed that physical activity might protect against ovarian cancer due to alterations in prostaglandin levels that may reduce ovarian epithelial inflammation [23]. Furthermore, physical activity may enhance the immune system by improving the capacity and number of killer cells [24]. However, frequent vigorous physical activity increases the level of circulating gonadotropines which may promote tumorgenesis in the ovary [25].

In this study, a prospective cohort study with a relatively large number of cases, we examine the effects of frequency, duration and intensity of different types of nonoccupational physical activity on the risk of ovarian cancer among post-menopausal women in the Netherlands.

\section{Materials and methods}

The cohort

This study is part of an ongoing prospective cohort study on diet and cancer, the Netherlands Cohort Study (NLCS) among 62,573 women aged 55-69 years at baseline. Baseline exposure data were collected by a mailed selfadministered questionnaire in September 1986 [5, 26]. Questions were asked about dietary habits and other risk factors for cancer. The study was designed as a case-cohort study, using all cases and a random sample of 2589 women from the cohort (subcohort), who have been followed for estimation of the accumulated person-years in the entire cohort [27]. This design has been chosen because of efficiency reasons; in a case-cohort design only the questionnaires of cases and subcohort members have to be processed and follow-up for person years can be restricted to the subcohort [26]. The cohort study had been approved by the Medical Ethical Committee of the University Hospital Maastricht/Maastricht University.

Follow-up

Incident cancer cases occurring in the total cohort have been identified by record linkage to The Netherlands cancer registry and the nationwide pathology register (PALGA). The method of record linkage has been described elsewhere [28]. The completeness of cancer follow-up was estimated to be at least 96\% [29], and no subcohort members were lost to follow-up. After 11.3 years of follow-up (September 1986 to December 1997), 278 incident primary epithelial ovarian cancer cases were available for analysis after exclusion of prevalent cancer cases at baseline other than non-melanoma skin cancer, of borderline invasive $(n=9)$, non-epithelial ovarian cancer cases $(n=9)$ and cases with missing information on physical activity $(n=4)$. In the subcohort, prevalent cancer cases at baseline other than non-melanoma skin cancer $(\mathrm{n}=151)$, as well as women who had an ovariectomy $(n=32)$ and women with missing information on physical activity $(n=53)$ were excluded, leaving 2353 subcohort members for analysis.

\section{Questionnaire}

In this paper we use the term "nonoccupational physical activity" to cover both recreational physical activity and the physical activity (e.g., walking and biking) involved in getting to and from work, to go shopping and to walk the dog. Occupational physical activity was not calculated, since most women of this generation had not held a job or had worked for only a short period of time, mostly in the distant past.

The questionnaire included two detailed questions on frequency, duration and type of current nonoccupational physical activity as well as history of sports participation. Baseline nonoccupational physical activity was assessed by three subquestions. First, we asked respondents how many minutes per day (on average) they did spend on physical activity related to transportation (like shopping, walking with the dog, biking to work). Then, frequency and duration of nonoccupational activities in hours per week was assessed, like gardening/doing odd jobs, biking/walking and sport/gymnastics. Possible answers were never, less than $1 \mathrm{~h}, 1-2 \mathrm{~h}$ or more than $2 \mathrm{~h}$ per week. We recoded these answers in $0,0.5,1.5$ and $2.5 \mathrm{~h}$ per week, respectively, and added the time spent on these activities (including daily biking/walking for transportation) up to an overall measure (minutes per day). Finally, respondents could indicate which type of sport they were currently 
Table 1 Distribution of potential confounders (mean and standard deviation or proportion) for baseline nonoccupational activity and history of sport participation among subcohort members in the Netherlands Cohort Study, 1986-1997

\begin{tabular}{|c|c|c|c|c|c|c|}
\hline & \multicolumn{4}{|c|}{$\begin{array}{l}\text { Baseline nonoccupational physical activity }(\mathrm{min} / \text { day): } \\
\text { Mean }(\mathrm{SD})^{\mathrm{a}} \text { or percentage }\end{array}$} & \multicolumn{2}{|c|}{$\begin{array}{l}\text { History of sport } \\
\text { participation: } \\
\text { Mean (SD) or percentage }\end{array}$} \\
\hline & $\begin{array}{l}<30 \text { min } \\
\text { per day }\end{array}$ & $\begin{array}{l}30-60 \min \\
\text { per day }\end{array}$ & $\begin{array}{l}60-90 \min \\
\text { per day }\end{array}$ & $\begin{array}{l}>90 \text { min } \\
\text { per day }\end{array}$ & No & Yes \\
\hline \multicolumn{7}{|l|}{ Potentially confounding variables: } \\
\hline Age (years) & $62.1(4.3)$ & $61.5(4.4)$ & $61.2(4.1)$ & $61.1(4.1)^{\mathrm{b}}$ & $61.7(4.3)$ & $61.2(4.2)^{\mathrm{b}}$ \\
\hline Age menarche (years) & $13.6(1.7)$ & $13.8(1.7)$ & $13.7(1.7)$ & $13.7(1.9)$ & $13.7(1.8)$ & $13.6(1.8)$ \\
\hline Age menopause (years) & $48.1(4.6)$ & $48.8(4.4)$ & $48.7(4.5)$ & $49.0(4.6)^{\mathrm{b}}$ & $48.5(4.6)$ & $48.9(4.4)$ \\
\hline Height $(\mathrm{cm})$ & $164.8(6.4)$ & $165.4(6.4)$ & $165.2(6.1)$ & $165.1(5.9)$ & $164.8(6.3)$ & $165.6(6.1)^{\mathrm{b}}$ \\
\hline BMI at baseline $\left(\mathrm{kg} / \mathrm{m}^{2}\right)$ & $25.6(3.8)$ & $25.0(3.5)$ & $25.0(3.5)$ & $24.8(3.2)^{\mathrm{b}}$ & $25.3(3.6)$ & $24.9(3.5)^{\mathrm{b}}$ \\
\hline Energy-intake at baseline (kcal/day) & $1638(402)$ & $1713(405)$ & $1684(380)$ & $1708(398)^{b}$ & $1678(391)$ & 1697 (407) \\
\hline Alcohol at baseline (g/day) & $4.9(8.8)$ & $6.0(9.2)$ & $6.2(9.2)$ & $6.1(10.6)$ & $4.9(8.8)$ & $6.8(10.1)^{\mathrm{b}}$ \\
\hline Number of children & $2.9(2.4)$ & $2.9(2.3)$ & $2.8(2.1)$ & $2.7(2.0)$ & $3.0(2.4)$ & $2.6(1.9)^{\mathrm{b}}$ \\
\hline Age first birth (years) & $21.5(11.2)$ & $22.1(11.1)$ & $22.3(10.9)$ & $22.3(10.7)$ & $21.8(11.0)$ & $22.4(11.0)$ \\
\hline $\begin{array}{c}\text { Family history of breast or } \\
\text { ovarian cancer ( } \% \text { yes })\end{array}$ & 8.6 & 9.0 & 8.1 & 9.4 & 9.0 & 8.4 \\
\hline Use of oral contraceptives ( $\%$ ever) & 20.8 & 24.3 & 24.6 & 28.6 & 21.1 & 28.4 \\
\hline Hysterectomy (\% yes) & 13.3 & 15.2 & 15.4 & 13.3 & 15.0 & 13.5 \\
\hline $\begin{array}{l}\text { Use of postmenopausal } \\
\text { hormones ( } \% \text { ever })\end{array}$ & 12.6 & 12.8 & 10.3 & 12.4 & 11.2 & 13.4 \\
\hline Current cigarette smoking ( $\%$ yes) & 21.6 & 18.5 & 25.2 & $20.6^{\mathrm{b}}$ & 19.6 & $23.4^{\mathrm{b}}$ \\
\hline
\end{tabular}

${ }^{a} \mathrm{SD}$, Standard deviation; BMI, body mass index

${ }^{\mathrm{b}} p<0.05$ (analysis of variance or chi-square)

performing. With respect to history of sports participation, we wanted to know what type of sport the respondent conducted, whether the respondent was active in a competition, how many hours per week (including training hours), and the duration of this sport in years. In total, respondents could describe three sports.

\section{Data analysis}

Distribution of the baseline nonoccupational physical activity and history of sports participation were compared for ovarian cancer cases and subcohort women. The following potential confounders were identified in literature and in our previous analyses [3, 6, 30, 31]: age (years), age at menarche (years), age at menopause (years), height $(\mathrm{cm})$, body mass index (BMI, $\left.\mathrm{kg} / \mathrm{m}^{2}\right)$, alcohol intake $(\mathrm{g} /$ day), parity (number of children), age at first child (years), family history of breast and/or ovarian cancer (yes versus no), use of oral anti-conceptives (ever versus never), hysterectomy (yes versus no), use of post-menopausal hormones (ever versus never), and smoking (ever versus never). Variables associated both with the risk for ovarian cancer and with physical activity, and that changed the rate ratios of physical activity with more than ten percent after inclusion in the analysis, were included in the multivariable analysis as confounders.

Rate ratios (RR) and corresponding 95\% confidence intervals (CI) for ovarian cancer were estimated in Cox proportional hazard models using 2001 Stata statistical software (release 7; Stata Corporation, College Station, Texas), after testing the proportional hazards assumption using scaled Schoenfeld residuals [32]. For subcohort members, person-time was calculated as the difference between the start of the follow-up period untill either date of death, date of emigration, date of ovarian cancer diagnosis or if none of the previously mentioned events occurred: the end date of the follow-up (31 December 1997). Cases, outside the subcohort, did not contribute to the person-time in the analysis. However, as the statistical model cannot calculate a person-time of zero, a negligible person-time of 0.0001 years was used for these cases.

Standard errors were estimated using the robust HuberWhite sandwich estimators to account for additional variance introduced by sampling person-time from the cohort [33]. Because preclinical disease might have influenced physical activity level, we repeated the multivariable analyses after excluding cases occurring in the first year of follow-up. Subgroup analyses on physical activity were conducted to evaluate potential interaction of use of oral anticonceptives, BMI, energy intake, and parity by total baseline nonoccupational physical activity, and history of sports. Energy-intake was calculated from the food frequency questionnaire using the computerized Dutch Food Composition table [34]. For these subgroup analyses energy intake was divided into quintiles and BMI into the categories normal weight $\left(<25 \mathrm{~kg} / \mathrm{m}^{2}\right)$, overweight 
$\left(25-<30 \mathrm{~kg} / \mathrm{m}^{2}\right)$ and obese $\left(30 \mathrm{~kg} / \mathrm{m}^{2}\right.$ and more). To obtain $p$ values for dose-response trends, we fitted ordinal exposure variables as continuous terms. Two-sided $p$ values are reported throughout the paper.

\section{Results}

In total, 278 cases of epithelial ovarian cancer were recorded in the Netherlands Cohort study after 11.3 years of follow-up. Cases spent, on average, less time on physical activity per day than women in the subcohort. With regard to sport history, cases were found to have a slightly lower sport participation in the past than subcohort members. Cases with a history of sport participation spent more hours on sport than subcohort members with a history of sport participation.

Women in the subcohort who spent more than $90 \mathrm{~min}$ per day on nonoccupational activity at baseline, had their menopause at an older age, a higher energy intake, and a lower BMI than women who were active less than $30 \mathrm{~min}$ per day (see Table 1). Women, who reported to ever have been engaged in a sport, were on average taller, had a lower BMI, drank more alcohol per day and had fewer children than women who never participated in any sport. Only the variables age, height, parity, the use of oral anticonceptives, and BMI appeared to be both risk factors for ovarian cancer as well as associated with physical activity. These variables were included as confounders in the subsequent multivariable analyses. For 252 cases and 2213 subcohort members information was available for all confounders.

For overall physical activity at baseline, we found in multivariable analyses that women who spent 30-60 min, 60-90 min, or more than $90 \mathrm{~min}$ per day on physical activity had a RR of 0.78 (95\% CI: 0.55, 1.09), 0.86 (95\% CI: $0.60,1.24)$, and 0.72 (95\% CI: $0.48,1.06)$, respectively, compared to women who spent less than half-anhour per day (see Table 2). The $p$ for trend was 0.15 . When looking at specific types of nonoccupational activities performed at baseline, we found that recreational biking and walking showed an inverse association with the risk of ovarian cancer. Women who walked or biked more than $2 \mathrm{~h}$ per week had a multivariable adjusted RR of 0.65 (95\% CI: $0.52,1.01)$, compared to women who never did this activity ( $p$ for trend, 0.05 ). Biking and walking to work, shopping and/or walking the dog was associated with statistically non-significant decreased risk ( $p$ for trend, 0.17). Gardening/doing odd jobs and sports/exercise were not associated with ovarian cancer risk.

For history of sports participation, we did not find an association with ovarian cancer risk. Women who ever participated in sports had a rate ratio of 1.01 (95\% CI: 0.77, 1.31) compared to women who were never active in sports. When looking at the number of hours sport per week, we did find increased risks, although not statistically significant ( $p$ for trend, 0.52). Duration of sports participation in years was not associated with the risk of ovarian cancer $(p$ for trend, 0.82).

When excluding cases diagnosed within the first year of follow-up, the rate ratios for physical activity and ovarian cancer did not differ substantially from the rate ratios including the first year of follow-up (results not shown).

Furthermore, we studied the interaction of other risk factors, such as use of oral anticonceptives, age, height, parity, and BMI on the association of physical activity (nonoccupational physical activity at baseline as well as sport history) and the risk of ovarian cancer (data not shown). No interaction was found.

\section{Discussion}

This prospective cohort study investigated the effect of frequency, duration and intensity of different types of physical activity on the risk of ovarian cancer among postmenopausal women in the Netherlands. In this cohort, we found no overall statistically significant association between nonoccupational physical activity and ovarian cancer risk, although the results suggest a modestly decreased risk of ovarian cancer for moderate physical activity.

The design of a prospective cohort study, like the NLCS, limits the possibility for selection bias. Selection bias is unlikely in our study due to the high completeness of follow-up of cases and person-years of the subcohort in the NLCS [29].

Assessing physical activity in epidemiological studies is difficult and various definitions and methods of measurement were used [35]. This may explain partly inconsistencies in results of studies on physical activity and ovarian cancer risk. Nonoccupational physical activity was reported by the respondents at baseline. It is conceivable that the physical activity of the participants changed during follow-up, resulting in bias that most likely lead to an attenuation of the risk ratios.

Baseline nonoccupational physical activity was measured by several aspects of habitual relatively recent physical activity such as gardening/doing odd jobs, biking/walking as leisure-time activity as well as for transportation (shopping, to and from work, walking the dog), and participating in sports/gymnastics. As an indicator of physical activity in the past, we limited ourselves to intensity and duration of performed sports in the past. We assume, however, that the baseline physical 
Table 2 Rate ratios (RR) and $95 \%$ confidence intervals for epithelial ovarian cancer according to nonoccupational physical activity, Netherlands Cohort Study on Diet and Cancer, 1986-1997

\footnotetext{
${ }^{\mathrm{a}} \mathrm{RR}$, rate ratio; CI, confidence interval. Rate ratios are given for cohort members with complete information on all confounders (252 cases and 2213 subcohort members)

${ }^{\mathrm{b}}$ Rate ratios multivariable adjusted for age at baseline (years), height $(\mathrm{cm})$, parity (number of children), age at first child (years), use of oral anticonceptives (ever versus never), and BMI $\left(\mathrm{kg} / \mathrm{m}^{2}\right)$
}

\begin{tabular}{|c|c|c|c|c|c|}
\hline & \multirow{2}{*}{$\begin{array}{l}\text { No. of cases/No. of } \\
\text { persons-years in } \\
\text { the subcohort }\end{array}$} & \multicolumn{2}{|c|}{ Age adjusted analyses } & \multicolumn{2}{|c|}{$\begin{array}{l}\text { Multivariable ad- } \\
\text { justed analyses }\end{array}$} \\
\hline & & $\mathrm{RR}^{\mathrm{a}}$ & $95 \% \mathrm{CI}^{\mathrm{a}}$ & $\mathrm{RR}^{\mathrm{b}}$ & $95 \% \mathrm{CI}$ \\
\hline \multicolumn{6}{|c|}{ Baseline nonoccupational physical activity } \\
\hline \multicolumn{6}{|l|}{ Total (in $\min /$ day) } \\
\hline$<30 \mathrm{~min} /$ day & $78 / 6030$ & 1 & Reference & 1 & Reference \\
\hline $30-<60 \mathrm{~min} /$ day & $76 / 7395$ & 0.78 & $0.56,1.10$ & 0.78 & $0.55,1.09$ \\
\hline $60-90 \mathrm{~min} /$ day & $57 / 5286$ & 0.87 & $0.60,1.25$ & 0.86 & $0.60,1.24$ \\
\hline \multirow[t]{2}{*}{$>90 \mathrm{~min} /$ day } & $44 / 5001$ & 0.71 & $0.48,1.05$ & 0.72 & $0.48,1.06$ \\
\hline & & \multicolumn{2}{|c|}{$p$ trend $=0.15$} & \multicolumn{2}{|c|}{$p$ trend $=0.15$} \\
\hline \multicolumn{6}{|c|}{ Biking/walking (to work, shopping, and/or walking the dog) } \\
\hline$<10 \mathrm{~min} /$ day & $87 / 7491$ & 1 & Reference & 1 & Reference \\
\hline $10-<30 \mathrm{~min} /$ day & $79 / 6696$ & 1.04 & $0.76,1.44$ & 1.07 & $0.78,1.49$ \\
\hline $30-<60 \mathrm{~min} /$ day & $59 / 6575$ & 0.80 & $0.56,1.13$ & 0.80 & $0.56,1.13$ \\
\hline \multirow[t]{2}{*}{$>60 \mathrm{~min} /$ day } & $27 / 2950$ & 0.82 & $0.52,1.29$ & 0.83 & $0.52,1.31$ \\
\hline & & \multicolumn{2}{|c|}{$p$ trend $=0.17$} & \multicolumn{2}{|c|}{$p$ trend $=0.17$} \\
\hline \multicolumn{6}{|c|}{ Biking/walking (recreational) } \\
\hline Never & $31 / 2049$ & 1 & Reference & 1 & Reference \\
\hline$<1 \mathrm{~h} /$ week & $68 / 5834$ & 0.77 & $0.50,1.18$ & 0.80 & $0.51,1.27$ \\
\hline $1-2 \mathrm{~h} /$ week & $78 / 7727$ & 0.67 & $0.44,1.01$ & 0.66 & $0.42,1.04$ \\
\hline \multirow[t]{2}{*}{$>2 \mathrm{~h} /$ week } & $75 / 8103$ & 0.63 & $0.42,0.96$ & 0.65 & $0.41,1.01$ \\
\hline & & \multicolumn{2}{|c|}{$p$ trend $=0.03$} & \multicolumn{2}{|c|}{$p$ trend $=0.05$} \\
\hline \multicolumn{6}{|c|}{ Gardening/doing odd jobs } \\
\hline Never & $103 / 9264$ & 1 & Reference & 1 & Reference \\
\hline$<1 \mathrm{~h} /$ week & $43 / 4364$ & 0.92 & $0.64,1.31$ & 0.95 & $0.65,1.39$ \\
\hline $1-2 \mathrm{~h} /$ week & $53 / 4828$ & 1.01 & $0.72,1.40$ & 1.00 & $0.70,1.42$ \\
\hline \multirow[t]{2}{*}{$>2 \mathrm{~h} /$ week } & $53 / 5257$ & 0.93 & $0.67,1.29$ & 0.92 & $0.65,1.31$ \\
\hline & & \multicolumn{2}{|c|}{$p$ trend $=0.76$} & \multicolumn{2}{|c|}{$p$ trend $=0.72$} \\
\hline \multicolumn{6}{|l|}{ Sports/exercise } \\
\hline Never & $179 / 15669$ & 1 & Reference & 1 & Reference \\
\hline$<1 \mathrm{~h} /$ week & $24 / 3143$ & 0.67 & $0.44,1.03$ & 0.70 & $0.45,1.10$ \\
\hline $1-2 \mathrm{~h} /$ week & $34 / 3481$ & 0.88 & $0.61,1.27$ & 0.92 & $0.62,1.36$ \\
\hline$>2 \mathrm{~h} /$ week & $15 / 1419$ & 0.98 & $0.58,1.66$ & 1.07 & $0.61,1.87$ \\
\hline & & & $d=0.86$ & & $d=0.70$ \\
\hline History of sports par & ation & & & & \\
\hline Never & $141 / 13269$ & 1 & Reference & 1 & Reference \\
\hline Ever & $111 / 10443$ & 1.02 & $0.80,1.31$ & 1.01 & $0.77,1.31$ \\
\hline No. of hours of spor & week & & & & \\
\hline$<1 \mathrm{~h} /$ week & $13 / 2037$ & 1 & Reference & 1 & Reference \\
\hline $1-2 \mathrm{~h} /$ week & $30 / 2340$ & 2.00 & $1.04,3.84$ & 2.01 & $1.02,3.99$ \\
\hline 2-3 h/week & $13 / 1347$ & 1.48 & $0.69,3.20$ & 1.44 & $0.65,3.23$ \\
\hline $3-5 \mathrm{~h} /$ week & $14 / 1649$ & 1.30 & $0.61,2.77$ & 1.25 & $0.56,2.77$ \\
\hline$>5 \mathrm{~h} /$ week & $33 / 2712$ & 1.90 & $1.00,3.61$ & 1.71 & $0.86,3.39$ \\
\hline & & & $d=0.27$ & & $d=0.52$ \\
\hline Duration of sports pe & pation (years) & & & & \\
\hline $1-10 \mathrm{yrs}$ & $53 / 5205$ & 1 & Reference & 1 & Reference \\
\hline $11-20 \mathrm{yrs}$ & $24 / 2021$ & 1.16 & $0.72,1.89$ & 1.13 & $0.67,1.91$ \\
\hline $21-30 \mathrm{yrs}$ & $8 / 862$ & 0.91 & $0.43,1.92$ & 0.90 & $0.41,1.97$ \\
\hline $31-40$ yrs & $9 / 611$ & 1.41 & $0.70,2.87$ & 1.36 & $0.63,2.95$ \\
\hline$>40 \mathrm{yrs}$ & $9 / 809$ & 1.06 & $0.52,2.15$ & 0.97 & $0.45,2.09$ \\
\hline & & & $d=0.63$ & & $d=0.82$ \\
\hline
\end{tabular}

activity will be an indicator also of physical activity in the past. Previous studies within the NLCS [5, 6] did find an inverse relation of physical activity and breast and endometrial cancer which is in agreement with a recent overview [4] and this is an indication that the questions used in this study are capable to measure physical activity adequately.
So far, few studies investigated the specific effect of biking or walking on cancer risk. A German study found that specifically biking and walking for transportation was significantly associated with a reduced risk for breast cancer. It was argued that the effect of biking and walking was stronger because these activities may be recalled better than other less frequently performed activities [35]. This 
type of recall bias may have influenced our findings as well and may explain why we observed a protective effect for biking and walking specifically. Biking either for transportation or for leisure time is very common in the Netherlands [36].

Our findings are consistent with the results of six casecontrol studies [7-12], and one prospective cohort that suggested a negative association [16]. One study had measured occupational physical activity only [7], three studies had measured both recreational and occupational physical activity $[9,11,12]$; while the other studies only had measured recreational physical activity. Results are difficult to compare because of differences in questionnaires, but also because cultural differences between populations with respect to physical activity in daily life. Two prospective studies found that particularly vigorous physical activity increased the risk of ovarian cancer among post-menopausal women $[14,15]$. In these studies risks were especially increased after more than four times per week vigorous sports activity [14] and for women with a score of 20-30 MET h/week [15]. In the Canadian casecontrol study [12] moderate physical activity was associated with a decreased risk of ovarian cancer, while vigorous physical activity was not. Other studies did not report differences between vigorous and moderate physical activity and risk of ovarian cancer $[10,11,16]$. In our study, we found inverse associations between biking and walking and ovarian cancer risk for post-menopausal women. This suggests that moderate physical activity of longer duration may reduce ovarian cancer risk.

It has been suggested that occupational and nonoccupational physical activity may be inversely associated and therefore occupational activity may confound studies of nonoccupational exercise. Women who have physically demanding jobs or tasks may have less energy for recreation than those who have more sedentary jobs $[10,15]$.

One case-control study found that specifically occupational physical activity was inversely associated with ovarian cancer risk [9]. A Finnish retrospective cohort study found no significant difference in ovarian cancer risk between physical education teachers and language teachers [13]. We did not study occupational physical activity in relation to the risk of ovarian cancer. In fact, the occupational history of women in the birth cohorts that were recruited for the NLCS tends to be limited. Before the 1960s, Dutch women usually stopped working after marriage or childbirth, so the occupational activity of many women (other than activities as a housewife) in this cohort was of short duration and/or took place long ago. The association between occupational physical activity and ovarian cancer can thus not be studied accurately in this population of Dutch women.

Another investigation within the NLCS found a significant positive association between height (and to a lesser extent body mass) and ovarian cancer incidence [30]. It has been suggested that height acts as a biomarker for an increased exposure to sex hormone and insulin-like growth factors [37, 38]. Physical activity during childhood may affect weight gain as well as hormone levels and insulinlike growth factors associated with an increased cancer risk. The age at which increased physical activity may optimally protect is unknown [39]. Further study on the effect of frequency and duration of both moderate physical activity and vigorous physical activity in premenopausal and post-menopausal women as well as the effect of changes in physical activity exposure is warranted.

In conclusion, we found a suggestion of an inverse association between moderate nonoccupational physical activity and ovarian cancer risk. Vigorous physical activity is not associated with ovarian cancer risk. Our findings support the hypothesis that regular moderate physical activity may reduce ovarian cancer risk among post-menopausal women.

Acknowledgements The authors thank the staff of the Dutch regional cancer registries and the Netherlands nationwide registry of pathology (PALGA) for providing incidence data. They also thank Dr Lex Volovics and Dr Arnold Kester for statistical advice; Sacha van de Crommert, Henny Brants, Jolanda Nelissen, Conny de Zwart, Marijke Moll, Margje Jansen, Willy van Dijk, and Annemie Pisters for data entry and processing; and Harry van Montfort, Ton van Moergastel, Linda van den Bosch, and Ruud Schmeitz for programming assistance. The Dutch Cancer Society financially supported The Netherlands Cohort Study.

\section{References}

1. Ferlay J, Bray F, Sankila R, Parkin D (1999) EUCAN: Cancer incidence, mortality and prevalence in the European Union 1997, version 4.1. IARC Press, Lyon (France)

2. Stewart B, Kleihues P (2003). World Cancer Report. IARC Press, Lyon

3. Weiss NS, Cook LS, Farrow DC, Rosenblatt KA (1996) Ovarian Cancer. In: Schottenfeld D, Fraumeni JF (eds) Oxford University Press, New York, pp 1040-1057

4. Vainio H, Bianchini F (2002) Weight Control and Physical Activity. IARC Handbooks of Cancer Prevention. Vol 6. IARC Press, Lyon

5. Dirx MJ, Voorrips LE, Goldbohm RA, van den Brandt PA (2001) Baseline recreational physical activity, history of sports participation, and postmenopausal breast carcinoma risk in the Netherlands Cohort Study. Cancer 92(6):1638-1649

6. Schouten LJ, Goldbohm RA, van den Brandt PA (2004) Anthropometry, physical activity, and endometrial cancer risk: results from the Netherlands Cohort Study. J Natl Cancer Inst 96(21):1635-1638

7. Zheng W, Shu XO, McLaughlin JK et al. (1993) Occupational physical activity and the incidence of cancer of the breast, corpus uteri, and ovary in Shanghai. Cancer 71(11):3620-3624

8. Cottreau CM, Ness RB, Kriska AM (2000) Physical activity and reduced risk of ovarian cancer. Obstet Gynecol 96(4):609-614

9. Tavani A, Gallus S, La Vecchia C et al. (2001) Physical activity and risk of ovarian cancer: an Italian case-control study. Int $\mathbf{J}$ Cancer 91(3):407-411 
10. Bertone ER, Newcomb PA, Willett WC, Stampfer MJ, Egan KM (2002) Recreational physical activity and ovarian cancer in a population-based case-control study. Int J Cancer 99(3):431-436

11. Zhang M, Lee AH, Binns CW (2003) Physical activity and epithelial ovarian cancer risk: a case-control study in China. Int J Cancer 105(6):838-843

12. Pan SY, Ugnat AM, Mao Y, (2005) Physical activity and the risk of ovarian cancer: A case-control study in Canada. Int J Cancer 117:300-307

13. Pukkala E, Poskiparta M, Apter D, Vihko V (1993) Life-long physical activity and cancer risk among Finnish female teachers. Eur J Cancer Prev 2(5):369-376

14. Anderson JP, Ross JA, Folsom AR (2004) Anthropometric variables, physical activity, and incidence of ovarian cancer: The Iowa Women's Health Study. Cancer 100(7):1515-1521

15. Bertone ER, Willett WC, Rosner BA et al. (2001) Prospective study of recreational physical activity and ovarian cancer. J Natl Cancer Inst 93(12):942-948

16. Hannan LM, Leitzmann MF, Lacey JV Jr et al. (2004) Physical activity and risk of ovarian cancer: a prospective cohort study in the United States. Cancer Epidemiol Biomarkers Prev 13(5):765770

17. Fathalla MF (1971) Incessant ovulation-a factor in ovarian neoplasia? Lancet 2(7716):163

18. Sternfeld B, Jacobs MK, Quesenberry CP Jr., Gold EB, Sowers M (2002) Physical activity and menstrual cycle characteristics in two prospective cohorts. Am J Epidemiol 156(5):402-409

19. Edmondson RJ, Monaghan JM (2001) The epidemiology of ovarian cancer. Int J Gynecol Cancer 11(6):423-429

20. Kramer MM, Wells CL (1996) Does physical activity reduce risk of estrogen-dependent cancer in women? Med Sci Sports Exerc 28(3):322-334

21. Friedenreich CM, Orenstein MR (2002) Physical activity and cancer prevention: etiologic evidence and biological mechanisms. J Nutr 132(11 Suppl):3456S-3464S

22. Risch HA (1998) Hormonal etiology of epithelial ovarian cancer, with a hypothesis concerning the role of androgens and progesterone [see comments]. J Natl Cancer Inst 90(23):1774-1786

23. Ness RB, Cottreau C (1999) Possible role of ovarian epithelial inflammation in ovarian cancer. J Natl Cancer Inst 91(17):14591467

24. Shepard RJ, Shek PN (1996) Impact of physical activity and sport on the immune system. Rev Environ Health 11(3):133-147

25. Cramer DW, Welch WR (1983) Determinants of ovarian cancer risk. II. Inferences regarding pathogenesis. J Natl Cancer Inst 71(4):717-721
26. van den Brandt PA, Goldbohm RA, van't Veer P et al. (1990) A large-scale prospective cohort study on diet and cancer in The Netherlands. J Clin Epidemiol 43(3):285-295

27. Volovics A, van den Brandt PA (1997) Methods for the analyses of case-cohort studies. Biom J 39:195-214

28. van den Brandt PA, Schouten LJ, Goldbohm RA, Dorant E, Hunen PM (1990) Development of a record linkage protocol for use in the Dutch Cancer Registry for Epidemiological Research. Int J Epidemiol 19(3):553-558

29. Goldbohm RA, van den Brandt PA, Dorant E (1994) Estimation of the coverage of Dutch municipalities by cancer registries and PALGA based on hospital discharge data. Tijdschr Soc Gezondheidsz 72:80-84

30. Schouten LJ, Goldbohm RA, Van Den Brandt PA (2003) Height, weight, weight change, and ovarian cancer risk in the Netherlands cohort study on diet and cancer. Am J Epidemiol 157(5):424-433

31. Gertig D, Hunter D (2002). Ovarian Cancer. In: Adami H-O, Hunter D, Trichopoulos D (eds) Textbook of Cancer Epidemiology. Oxford University Press, Oxford, 378-399

32. Schoenfeld D (1982) Partial residuals for the proportional hazards regression model. Biometrika 69:239-241

33. Lin DY, Wei LJ (1989) The robust inference for the Cox Proportional Hazards Model. J Am Stat Assoc 84:1074-1078

34. Stichting NEVO (1986) NEVO-tabel; Nederlands Voedingsstoffenbestand 1986-1987. The Hague: Voorlichtingsbureau voor de Voeding

35. Steindorf K, Schmidt M, Kropp S, Chang-Claude J (2003) Casecontrol study of physical activity and breast cancer risk among premenopausal women in Germany. Am $\mathrm{J}$ Epidemiol 157(2):121-130

36. Haftenberger M, Schuit AJ, Tormo MJ et al. (2002) Physical activity of subjects aged 50-64 years involved in the European Prospective Investigation into Cancer and Nutrition (EPIC). Public Health Nutr 5(6B):1163-1176

37. Gunnell D, Okasha M, Davey Smith G, Sandhu J, Holly JM (2001) Height, leg length, and cancer risk: a systematic review. Epidemiol Rev 23(2):313-336

38. Yu H, Rohan T (2000) Role of the insulin-like growth factor family in cancer development and progression. J Natl Cancer Inst 92(18):1472-1489

39. McTiernan A, Ulrich C, Slate S, Potter J (1998) Physical activity and cancer etiology: associations and mechanisms. Cancer Causes Control 9(5):487-509 